\title{
Protective effect of silymarin on the testes of rats treated with anabolic androgenic steroid: A biochemical, histological, histochemical and immunohistochemical study
}

Hala M. El-hanbuli ${ }^{*}$, Ahmed F. Abo-sief ${ }^{2}$ and Taymour Mostafa ${ }^{3}$

*Correspondence: hmh06@fayoum.edu.eg

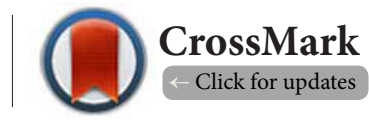

'Department of Pathology, Faculty of Medicine, Fayoum University, Egypt.

${ }^{2}$ Department of andrology, Sexology\& STDs, Faculty of Medicine, Beni-suef University, Egypt.

${ }^{3}$ Department of andrology, Sexology\& STDs, Faculty of Medicine, Cairo University, Egypt.

\begin{abstract}
Background: Many harmful effects have been reported for the abuse of testosterone with supraphysiologic doses on the male genital system.

Objective: To study the possible protective effect of silymarin in testosterone induced testicular changes.

Materials and Methods: Eighty adult male albino rats were randomly divided into four groups; untreated rats (controls), rats treated with silymarin, rats treated with testosterone and rats treated with testosterone and silymarin. Relative testicular weight, serum testosterone and FSH were estimated in addition to histological, histochemical and immunohistochemical assessment.

Results: Serum testosterone was significantly higher in testosterone treated rats compared with the controls and rats treated with testosterone plus silymarin. Serum FSH was significantly lower in testosterone treated rats as well as rats treated with silymarin plus testosterone compared with controls. There was a significant increase in caspase- 3 expression between testosterone treated rats and the other studied groups $(\mathrm{P}<0.001)$. There was a significant increase in P53 expression between the testosterone treated rats and the control groups $(\mathrm{P}<0.001$ for each), and also between the testosterone treated rats and rats treated with testosterone and silymarin $(\mathrm{P}=0.004)$. $\mathrm{P} 53$ expression was also significantly different between rats treated with testosterone plus silymarin and the control groups ( $\mathrm{P}=0.012$ for each).

Conclusion: Oral concomitant treatment with silymarin was effective in attenuating testosterone- induced testicular damage in adult male albino rats.
\end{abstract}

Keywords: Testosterone, testis, apoptosis, caspase, P53

\section{Introduction}

Androgens play an important role in male reproductive organs development, and are of major importance in puberty, fertility, and sexual function. Leydig cells secrete intra-testicular testosterone which is a steroid hormone that has a great importance in the development of the male phenotype and regulation of reproduction as it is essential for spermatogenesis $[\mathbf{1 , 2}]$.

Anabolic-androgenic steroids (AAS) are natural and synthetic compounds that are analogues to the male sex hormones. Their medical utilization is limited and they areonly used with great caution in some disorders such as poor growth, osteoporosis, hypogonadism and anemia [3]. AAS in supraphysiological doses can enhance athletic performance. However, these compounds could be abused by athletes to increase their muscle mass by increasing protein synthesis [4]. On the other hand, AAS abuse can lead to some harmful side effects such as liver failure and decrease high density lipoprotein levels, acne vulgaris, gynaecomastia, cholestasis, and renal failure $[5,6]$. AAS also might cause side effects in the reproductive systems, both in human and experimental animals, disturbing the regular endogenous 
production of testosterone and gonadotrophins [7].

Sustanon is one of AAS, which is used to treat several cases in andrology such as male hypogonadism and infertility [8]. It is characterized by a unique structure and properties compared with the other AAS drugs in the market as it is composed of a mixture of four different testosterone esters [9]. Many harmful effects have been reported for Sustanon abuse on the male reproductive health as high level of testosterone induces oxidative stress by alteration of the balance between reactive oxygen species (ROS) production and antioxidant defenses [10]. Free radicals have many harmful effects including lipid peroxidation, DNA damage and apoptosis [11].

Lately, much attention has been paid on using plantderived materials including various forms of extracts as an antioxidant source to eliminate excessive ROS [12-14]. Silymarin, the active components of milk thistle extract, is a flavonoid polyphenolic compound extracted from Silybummarianum seeds that has long been extensively used in patients suffering from liver disease. It has also other biological activities as anti-inflammatory, antioxidant and anti-cancer properties both in in-vitro and in-vivo studies [15-18].

Some studies have been performed on the protective effects of silymarin on male reproduction but have not been completed yet and the mechanism of its action on sex hormones has not been clearly examined [19]. In addition, its possible protective effects against anabolic steroids related testicular adverse effect has no previous attention.

The harmful effects of Sustanon on testes have been confirmed in several studies; however to the best of our knowledge, no single work has studied its possible protective effect in Sustanon induced testicular changes. So, this study aimed to assess the possible protective effect of Silymarin in Sustanon induced testicular changes in rats.

\section{Materials and methods}

This experimental study was approved by the Ethical Committee of Research, Faculty of Medicine with conformity to institutional and national guidelines for the care and use of animals. Eighty adult male albino rats were used (weight 135$150 \mathrm{~g}$ ). They were caged individually and they were randomly divided into 4 equal groups ( $n=20$ each) as follows:

- Group 1. Untreated control rats fed on ordinary chew plus saline (the vehicle).

- Group 2. Rats treated by silymarin orally ( $20 \mathrm{mg} / \mathrm{kg} /$ day).

- Group 3: Rats injected with IM testosterone (SustanonR, Organon, India) (10 mg/kg/week).

- Group 4. Rats treated by silymarin ( $20 \mathrm{mg} / \mathrm{kg} /$ day) orally and IM Sustanon (10 mg/kg/week).

Sustanon ${ }^{R} 250 \mathrm{mg}$ ampule is one of AAS that is composed of an oily mixture of four testosterone esters that provide a permanent release of testosterone into the blood for length level from 3-4 weeks (30 mg testosterone propionate, $60 \mathrm{mg}$ testosterone phenylpropionate, $60 \mathrm{mg}$ testosterone isocaproate and $100 \mathrm{mg}$ testosterone decanoate).
Following treatment for 8 weeks, all rats were sacrificed and their testes were removed immediately and weighed for their relative weight (testes weight/body weight X100). Also, blood samples were collected for determination of serum follicle stimulating hormone (FSH) and total testosterone hormone (T).

\section{Biochemistry}

Quantitative measurement of both total testosterone [20] and FSH [21] was done using IMMULITE analyzer (Catalog number: LKTW1).

\section{Histopathology, histochemistry and Immunohisto- chemistry studies}

The removed testes were immediately excised and fixed in $10 \%$ neutral buffered formalin. Paraffin sections $(5 \mu \mathrm{m})$ were prepared for processing the histological, histochemical and immunohistochemical studies. For histology, the sections were stained with haematoxylin and Eosin ( $\mathrm{Hx}$ \& E). Leydig cells in interstitial connective tissue were counted under $400 \mathrm{X}$ in five distinct microscopic fields for each rat.For histochemical studies, Periodic acid Schiff's (PAS) reaction was used for demonstration of polysaccharides [22].

For immunohistochemistry using Caspase- 3 and P53 antibodies, deparaffinized, rehydrated sections were heated in a microwave oven in $10 \mathrm{mmol} / \mathrm{L}$ citrate buffer $(\mathrm{pH} 6)$ for antigen retrieval. The sections were immersed in $0.3 \% \mathrm{H}_{2} \mathrm{O}_{2}$ in methanol to block endogenous peroxidase and were pre-incubated with normal mouse or rabbit serum to block nonspecific binding of antibodies. The sections were then incubated with primary antibody. The avidin-biotin-peroxidase-complex method was used for detection, with diaminobenzidine tetrachloride as the chromogen. The primary antibodies used were rabbit polyclonal Caspase-3 antibody (CPP32) (1:100; Thermo Fisher Scientific Co., USA) and rabbit polyclonal P53 antibody (ab131442) (1:100; abcam, USA). As a negative control for immunostaining, the second antibody was used without the first antibody for each protein. Immunostained germ cells were identified in a minimum of 1000 germ cells examined in the testes by light microscopy at 400X in 5 random fields. For Caspase-3 both nuclear and cytoplasmic staining were observed, however nuclear staining only was used in scoring. Only nuclear staining was detected for P53. For scoring of both markers the number of stained germ cell nuclei was expressed relative to the total number of germ cell nuclei in the seminiferous tubules in each testis and then was expressed as percentages. This percentage is then converted to grades namely (0) no staining, (1) $0-5 \%$, (2) 6-50\% and (3) $>50 \%$ [23].

\section{Statistical analysis}

Statistical analysis was done using SPSS statistical software package version 21 (SPSS Inc., Chicago, IL, USA). The results were presented as mean and standard deviation (SD) for quantitative data, frequencies and percent for qualitative data. Chi-square test was used for comparing qualitative variables 
between groups. ANOVA test followed by post-hoc tests was used for intergroup comparison of quantitative variables. Correlation between quantitative variables was presented by Pearson correlation co-efficient $P$ value $<0.05$ was set as statistically significant.

\section{Results}

\section{Relative testicular weight and hormones}

There was significant decreases in testicular weights in testosterone treated rats compared with the controls whereas the mean testis weight in testosterone and silymarin treated rats showed nonsignificant difference compared with the controls. Serum testosterone was significantly higher in testosterone treated rats compared with the controls and rats treated with testosterone plus silymarin. Serum FSH was significantly lower in testosterone treated rats as well as the rats treated with silymarin plus testosterone compared with the controls (Table 1).

\section{Histopathological examination}

Light microscopic examination of $\mathrm{Hx} \& \mathrm{E}$ stained sections of testes of the control group (Figure 1A) and controls treated with silymarin (Figure 1B) revealed normal histological appearance of the seminiferous tubules, germ cells with sperm formation and interstitial Leydig cells. In testosterone treated rats (Figure 1C), the testes showed degeneration, disorganization, reduced number of mature sperms, necrotic debris, decreased spermatogenic cells, decreased spermatogenic layers with reduced diameter in most seminiferous tubules and atrophy/ hyalinization in some of them with dilated interstitial spaces and apparently reduced number of randomly distributed

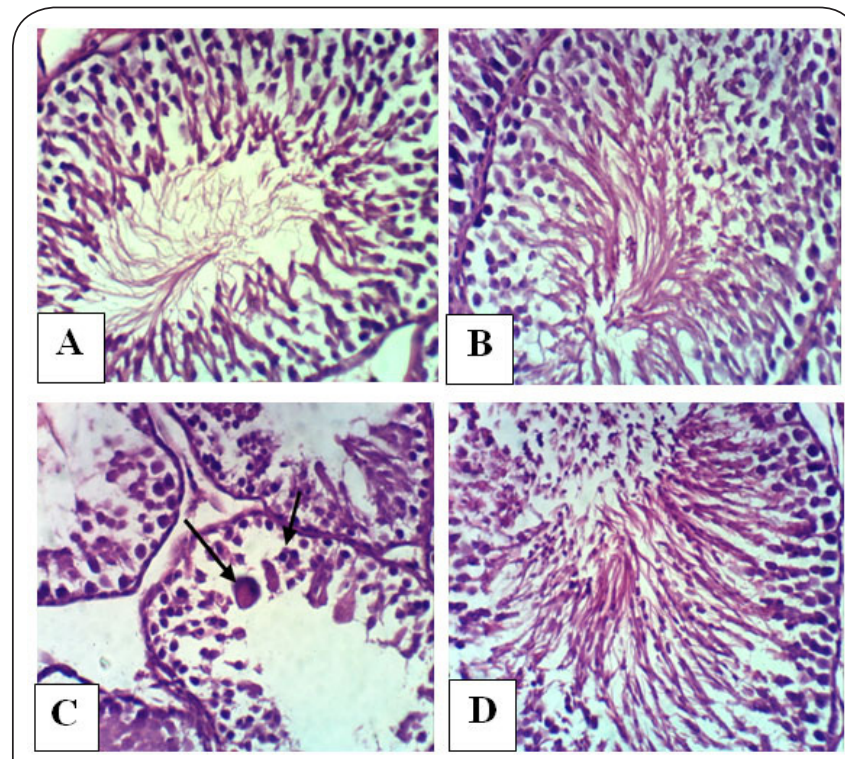

Figure 1. Seminiferous tubules of rat testes of the four studied groups (Hx \&E X400) (A) Testis of one of the untreated control group and (B) of control received silymarin; both showing normal seminiferous tubules with normal spermatogoneal cells and complete spermatogenesis with sperm production. (C) Testis of testosterone treated rat showing degeneration and necrosis of spermatogoneal cells lining seminiferous tubules with formation of spermatid giant cells (arrows), interstitial edema and loss of Leydig cells. (D) Testis of rat treated with testosterone and silymarin showing normal histological structure of semineferous tubules.

Leydig cells. In rats that received testosterone and silymarin (Figure 1D), the testes showed relatively normal histological

Table 1. Comparison of the four studied rat groups (mean \pm SD).

\begin{tabular}{|c|c|c|c|c|}
\hline & $\begin{array}{l}\text { Untreated } \\
\text { controls }\end{array}$ & $\begin{array}{l}\text { Controls+ } \\
\text { silymarin }\end{array}$ & $\begin{array}{l}\text { Rats on } \\
\text { testosterone }\end{array}$ & $\begin{array}{l}\text { Rats on } \\
\text { testosterone+ silymarin }\end{array}$ \\
\hline $\begin{array}{l}\text { Relative testicular weight (\%) } \\
\text { P1 } \\
\text { P2 } \\
\text { P3 }\end{array}$ & $2.35 \pm 0.4$ & $\begin{array}{l}2.28 \pm 0.2 \\
0.274\end{array}$ & $\begin{array}{l}1.98 \pm 0.1 \\
<\mathbf{0 . 0 0 1} \\
<\mathbf{0 . 0 0 1}\end{array}$ & $\begin{array}{l}2.34 \pm 0.2 \\
0.875 \\
0.348 \\
<\mathbf{0 . 0 0 1}^{\star}\end{array}$ \\
\hline $\begin{array}{l}\text { Serum Testosterone }(\mathbf{n g} / \mathbf{m l}) \\
\text { P1 } \\
\text { P2 } \\
\text { P3 }\end{array}$ & $7.75 \pm 0.4$ & $\begin{array}{l}7.68 \pm 0.4 \\
0.858\end{array}$ & $\begin{array}{l}10.84 \pm 1.9 \\
<\mathbf{0 . 0 0 1}^{\star} \\
<\mathbf{0 . 0 0 1}^{\star}\end{array}$ & $\begin{array}{l}9.6 \pm 1.4 \\
<0.001^{\star} \\
<0.001^{\star} \\
0.002^{\star}\end{array}$ \\
\hline $\begin{array}{l}\text { Serum FSH }(\mathrm{U} / \mathrm{ml}) \\
\text { P1 } \\
\text { P2 } \\
\text { P3 }\end{array}$ & $2.59 \pm 0.42$ & $\begin{array}{l}2.64 \pm 0.3 \\
0.633\end{array}$ & $\begin{array}{l}1.1 \pm 0.4 \\
<\mathbf{0 . 0 0 1} 1^{\star} \\
<\mathbf{0 . 0 0 1}\end{array}$ & $\begin{array}{l}1.31 \pm 0.3 \\
<\mathbf{0 . 0 0 1} \\
<\mathbf{0 . 0 0 1} \\
0.061\end{array}$ \\
\hline $\begin{array}{l}\text { Leydig cell count } \\
\text { P1 } \\
\text { P2 } \\
\text { P3 }\end{array}$ & $20.5 \pm 1.5$ & $\begin{array}{l}20.6 \pm 1.6 \\
0.839\end{array}$ & $\begin{array}{l}12.8 \pm 1.6 \\
<\mathbf{0 . 0 0 1} \\
<\mathbf{0 . 0 0 1}\end{array}$ & $\begin{array}{l}18.8 \pm 1.4 \\
0.001^{\star} \\
<0.001^{\star} \\
<\mathbf{0 . 0 0 1}^{\star}\end{array}$ \\
\hline
\end{tabular}

*Significant at $P<0.05$

P1 comparison with untreated controls

P2 comparison with control rats treated with silymarin

$\mathrm{P} 1$ comparison with rats treated with testosterone. 
El-hanbuli et al. Journal of Histology \& Histopathology 2017,

http://www.hoajonline.com/journals/pdf/2055-091X-4-10.pdf

appearance of most seminiferous tubules and Leydig cells.

Leydig cell count was significantly different in testosterone treated rats compared with the controls and significantly different in testosterone plus silymarin received rats from the two control groups and testosterone only received group (Table 1).

\section{Histochemical observations}

The testes of the untreated control group (Figure 2A) and rats treated with silymarin (Figure $2 \mathrm{~B}$ ) showed normal distribution of PAS positive reaction in the tunica albuginea and intertubular connective tissue, while the testes of the rats that received testosterone showed reduced staining affinity with interstitial edema (Figure $\mathbf{2 C}$ ). In rats that received testosterone and silymarin (Figure 2D), the PAS positive material showed normal distribution in the testis.

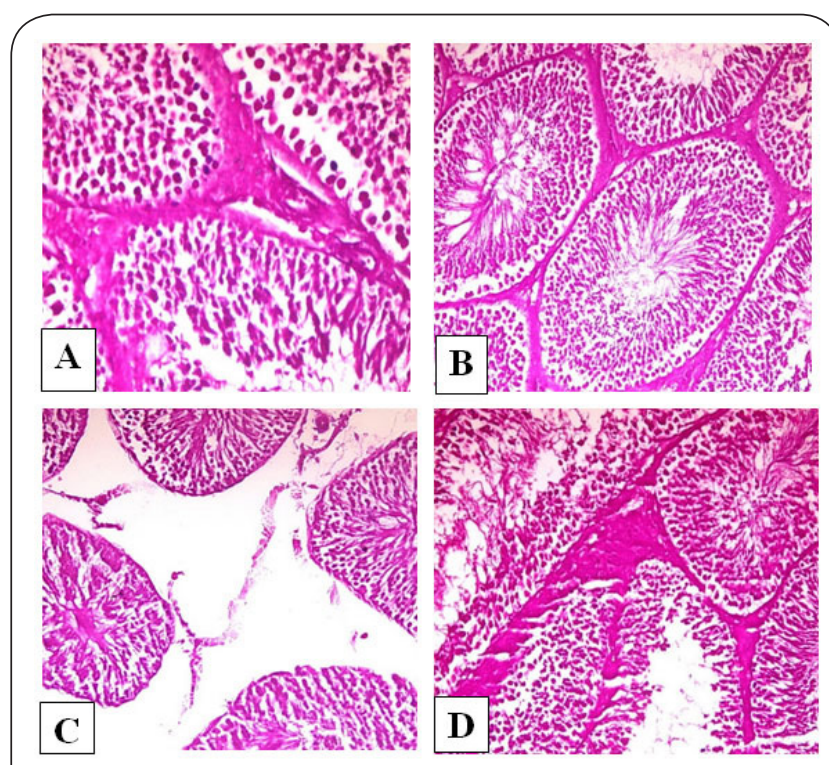

Figure 2. Distribution of PAS +ve material in testis of untreated rats (A)(X400) and control received silymarin (B) (X200) both showing strong reaction in the boundaries of the seminiferous tubules and in intertubular connective tissue. Testis of testosterone treated rat (C) (X200) showing marked decrease of PAS +ve material with interstitial edema. Testis of rat treated with testosterone and silymarin (D) showing nearly normal content of PAS +ve material (X 200).

\section{Immunohistochemical observation}

Immunohistochemical staining for Caspase-3 was represented in (Figure 3). The grades of staining for the untreated control group ranged from 0 to 2 and from 0 to 1 for the silymarin treated rats, while for the testosterone treated rats the grades ranged from 2 to 3 and from 0 to 1 for testosterone plus silymarin treated rats. There was a significant difference in Caspase- 3 expression between testosterone treated rats and all other studied groups $(\mathrm{P}<0.001)$.

Immunohistochemical staining for P53 was represented in (Figure 4). Both control groups showed negative staining (Grade 0 ). The grades of staining for the testosterone treated

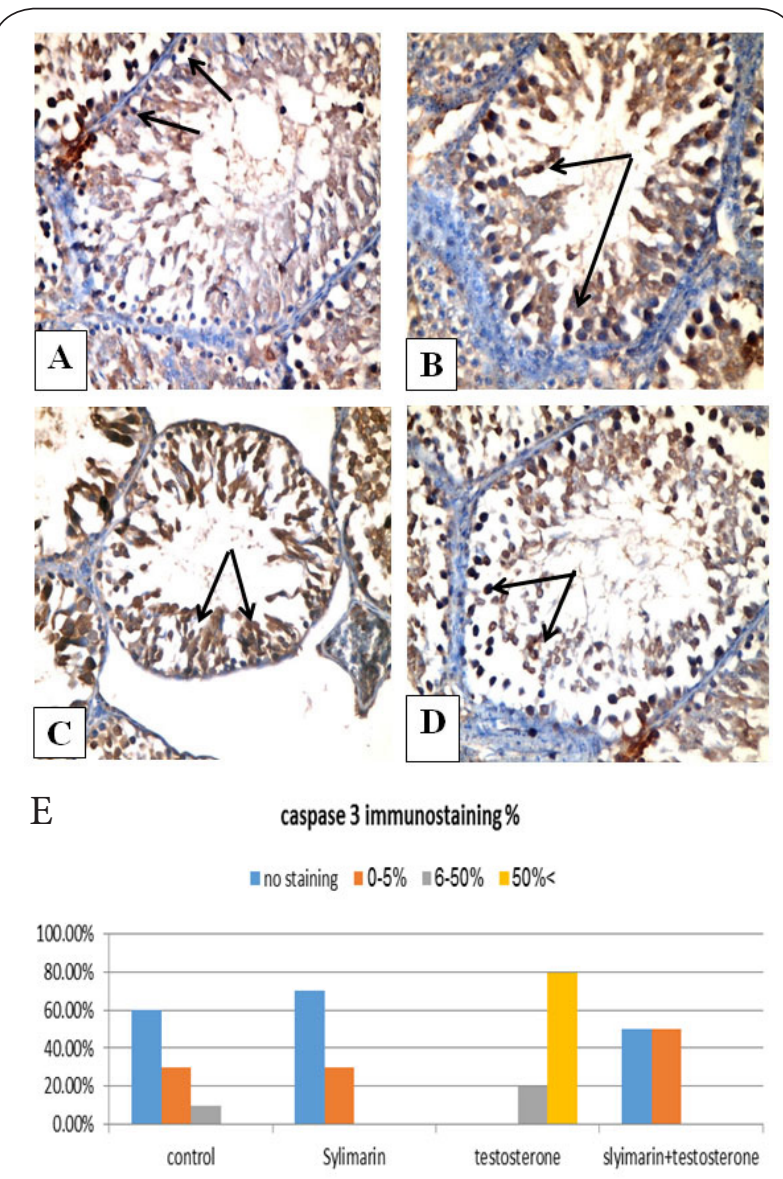

Figure 3. Immunohistochemical expression of Caspase-3 antibody in rat testes (arrows) (A-D) (X400): (A) Testis of untreated control rat, (B)Testis of control rat received silymarin, (C) Testis of testosterone treated rat showing markedly increased number of nuclear stained germ cells (D) Testis of rat treated with testosterone and silymarin. Comparison of the immunohistochemical expression of Caspase 3 in rat testes in the four studied groups (E).

group ranged from 0 to 3 , and from 0 to 1 for the testosterone and silymarin treated group. There was a significant difference in P53 expression between the testosterone treated group and the control groups ( $\mathrm{P}<0.001$ for each), and also between the testosterone treated group and the group treated with testosterone and silymarin $(P=0.004)$. $P 53$ expression was also significantly different between the group treated with testosterone and silymarin and the control groups $(P=0.012$ for each).

\section{Discussion}

Lately, the deliberate abuse of anabolic androgenic drugs especially testosterone derivatives by athletes have increased rapidly world-wide. Meanwhile, their reproductive effects include many hazards as some researchers found that the anabolic steroids treated rats showed reduction in the number of spermatogonia leading to decreased sperm count and 


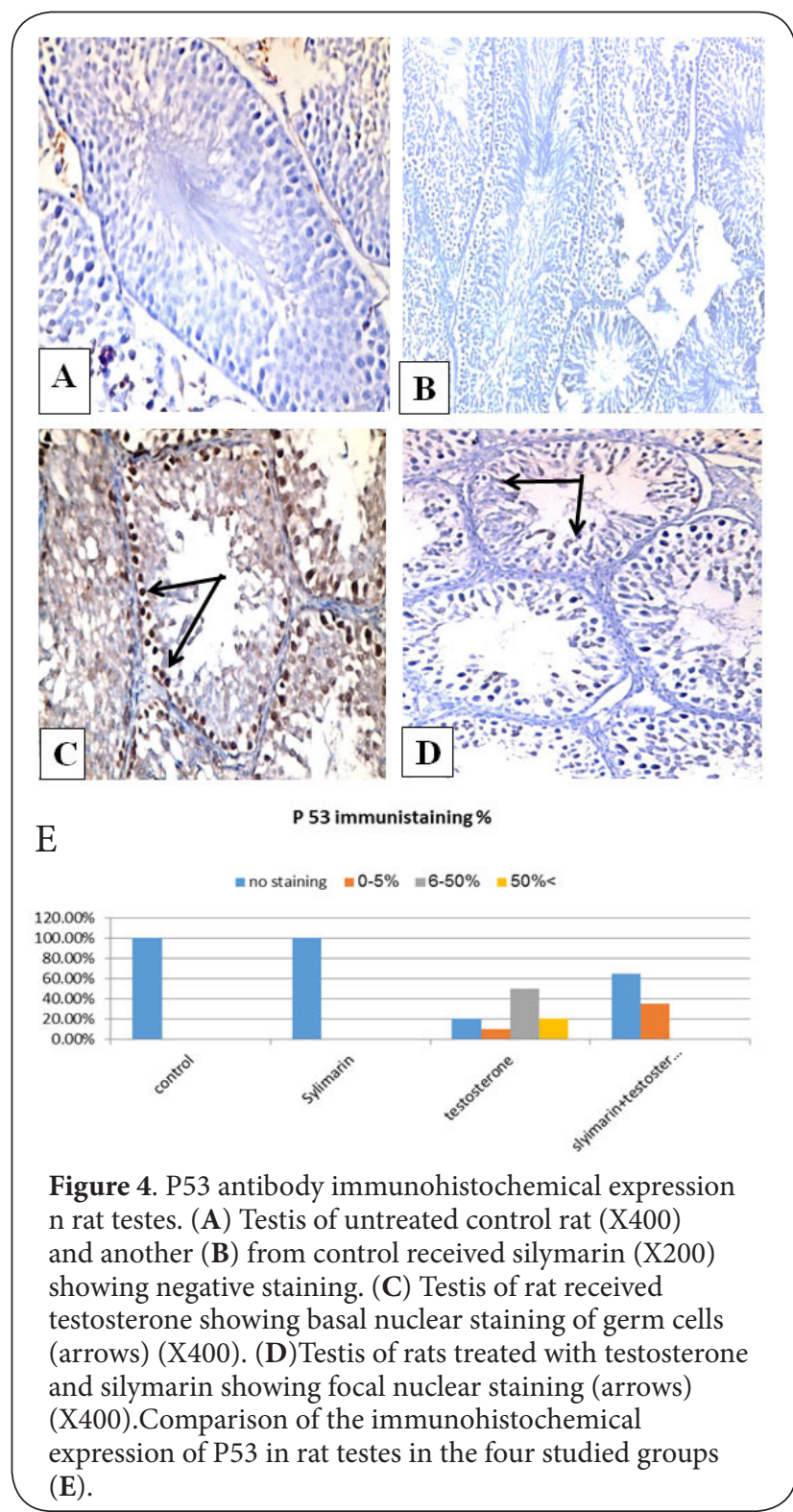

testicular atrophy $[\mathbf{5}, \mathbf{2 5}]$. Within the testes, the main target cells for toxicants are always the somatic cells (Leydig and Sertoli cells) and germ cells which results in apoptosis and spermatogenic failure [26].

This study reported a significant reduction in the mean testicular weight in testosterone treated rats compared with the controls. In their study, Mutalip et al. [27] reported significant decreases in the testes absolute weight in two groups of male Sprague-Dawley rats, one injected with testosterone and the other with an anabolic steroids for six weeks. Also, De Souza [28] reported similar results in Wistar rats that were treated with testosterone esters mixture.

There was significant increases in serum testosterone and significant decreases in serum FSH in testosterone treated rats. Some studies [29-31] confirmed that administration of testosterone and its derivatives causes elevated of serum testosterone. Also, these hormonal changes can be explained by that exogenous administration of testosterone suppresses both $\mathrm{GnRH}$ and $\mathrm{LH}$ production and subsequently suppress testicular testosterone production [1,32]. However, Al-Alwany et al. [33] reported that when testosterone was injected to three groups of albino rats in doses of $(0.05,0.1$ and 0.2$) \mathrm{mg} /$ $\mathrm{kg} /$ day for six weeks there was a significant increase in the mean levels of FSH hormone. They explained that the increase in testosterone level of athletes can cause increase secretion of FSH from hypothalamus pituitary gland.

The histopathological changes detected in testosterone treated rats was similar to that observed in other study after administration of three different doses of testosterone to three groups of rats weekly for four weeks [31] and also on studying the histological changes in rat testes after injection of repeated weekly administration of two doses of testosterone for two months [34]. However, Mutalip et al. [27] reported that testicular histology of rats treated with testosterone or stanozolol showed slight changes. Other studies [35-38] reported severe depletion of Leydig cells when treated by AAS and a significant decrease in the number and size of the interstitial cells of Leydig compared with controls. This all goes with the results of this study.

There was a reduction in PAS positive reaction in the testosterone treated group of rats compared with the controls. Similar observations were reported by many observers $[39,40]$ in the testes of mice intoxicated with different factors. It was postulated that the decrease in proteins could be attributed to disruption of lysosomal membranes under the effect of various toxicants liberating their hydrolytic enzymes with marked lysis of the target materials.

In apoptosis, caspases play a crucial role in the transduction of apoptotic signals in cells that are destined to die [41], also, P53 protein regulates cell cycle inhibition, DNA repair and apoptosis in response to DNA damage. Thus, it serves as a checkpoint control mechanism and protects the cell from harmful propagation of DNA damage [42].

The significant increase in caspase- 3 immunohistochemical staining of germ cells compared with the controls was also observed by Kim et al. [43] in the testes of rats received testosterone and this was explained as that germ cell apoptosis resulted from a reduced intratesticular testosterone concentration is caspase-3 activation dependent.

Absence of P53 immunohistochemical expression in germ cells of controls is similar to that found by other researchers $[44,45]$. This expression may be related to testosterone related testicular damage; as p53 can be highly expressed in testes under cellular stress as its intracellular concentration increase to a level that can be detected $[46,47]$.

Silymarin has also been reported to have antioxidant, antiinflammatory and immunomodulatory effects [48]. The current study showed that rats that received testosterone and silymarin had significantly better results than that of testosterone only 
treated rats regarding all variables examined except for FSH level that showed nonsignificant difference. It is worth mention that all these studied variables are significantly different compared with the controls except for the relative testicular weight and caspase-3 immunohistochemical expression.

It is known that testosterone administration causes oxidative stress [10]. So the improved variables detected in this study could be attributed to both antioxidants and inhibitory effect of free radicals formation [49]. In their study, Moshtaghion et al. [50] showed that silymarin-treated animals were protected from varicocele-induced testicular atrophy and these animals showed a significant increase in the percentage of seminiferous tubules with positive tubular differentiation, repopulation, and spermiogenesis indices.

It is concluded that oral treatment with silymarin is effective in attenuating testosterone-induced biochemical and histopathological damage in adult male albino rats. These facts could present an approach for managing AAS abuse.

Competing interests

The authors declare that they have no competing interests.

Authors' contributions

\begin{tabular}{|l|c|c|c|}
\hline Authors' contributions & HME & AFA & TM \\
\hline Research concept and design & $\checkmark$ & $\checkmark$ & $\checkmark$ \\
\hline Collection and/or assembly of data & $\checkmark$ & $\checkmark$ & $\checkmark$ \\
\hline Data analysis and interpretation & $\checkmark$ & $\checkmark$ & $\checkmark$ \\
\hline Writing the article & $\checkmark$ & $\checkmark$ & $\checkmark$ \\
\hline Critical revision of the article & $\checkmark$ & $\checkmark$ & $\checkmark$ \\
\hline Final approval of article & $\checkmark$ & $\checkmark$ & $\checkmark$ \\
\hline Statistical analysis & $\checkmark$ & $\checkmark$ & $\checkmark$ \\
\hline
\end{tabular}

Publication history

EIC: Gaetano Giuseppe Magro, University of Catania, Italy. Received: 08-Aug-2017 Final Revised: 09-Sep-2017

Accepted: 12-Sep-2017 Published: 25-Sep-2017

\section{References}

1. Dohle GR, Smit M and Weber RF. Androgens and male fertility. World J Urol. 2003; 21:341-5. | Article | PubMed

2. Lee D-M, Min T, Choi I, Cheon Y-P, Chun T, Park CS and Lee K-H. Feeding effect of an anabolic steroid, nandrolone, on the male rat testis. AsianAust J Anim Sci. 2010; 23:1566-1577. | Article

3. Naraghi MA, Abolhasani F, Kashani I, Anarkooli IJ, Hemadi M, Azami A, Barbarestani M, Aitken RJ and Shokri S. The effects of swimming exercise and supraphysiological doses of nandrolone decanoate on the testis in adult male rats: a transmission electron microscope study. Folia Morphol (Warsz). 2010; 69:138-46. | PubMed

4. Birgner C, Kindlundh-Hogberg AM, Oreland L, Alsio J, Lindblom J, Schioth $\mathrm{HB}$ and Bergstrom $\mathrm{L}$. Reduced activity of monoamine oxidase in the rat brain following repeated nandrolone decanoate administration. Brain Res. 2008; 1219:103-10. | Article | PubMed

5. Tahtamouni L, Mustafa NH, Hassan EM, Ahmad IM, Yasin SR and Abdalla MY. Nandrolone decanoate administration to male rats induces oxidative stress, seminiferous tubules abnormalities, and sperm DNA fragmentation. JJBS. 2010; 3:165-174. | Pdf

6. Rahnema CD, Crosnoe LE and Kim ED. Designer steroids - over-thecounter supplements and their androgenic component: review of an increasing problem. Andrology. 2015; 3:150-5. | Article | PubMed
7. Kanayama G, Hudson JI, DeLuca J, Isaacs S, Baggish A, Weiner R, Bhasin $S$ and Pope HG, Jr. Prolonged hypogonadism in males following withdrawal from anabolic-androgenic steroids: an under-recognized problem. Addiction. 2015; 110:823-31. | Article | PubMed Abstract | PubMed FullText

8. Harvey R. A. and Champe P.C. The Lippincotts Illustrated Reviews of Pharmacology, 2nd Edn., JB Lippincott Co., New York, USA. 2002.

9. Beotra A. Drug Abuse, $2^{\text {nd }}$ Ed., Pharaceutical Press Publishing, London, UK. 822. 2005.

10. Alonso-Alvarez C, Bertrand S, Faivre B, Chastel O and Sorci G. Testosterone and oxidative stress: the oxidation handicap hypothesis. Proc Biol Sci. 2007; 274:819-25. | Article | PubMed Abstract | PubMed FullText

11. Kothari S, Thompson A, Agarwal A and du Plessis SS. Free radicals: their beneficial and detrimental effects on sperm function. Indian J Exp Biol. 2010; 48:425-35. | PubMed

12. Ozkol $H$, Tuluce $Y$ and Koyuncu I. Some medicinal plants counteract alterations of neuroendocrine stress response system oxidative and nitrosative stress caused by repeated restraint in rats. $J$ Med Plant Res. 2011; 5:4360-4368. | Article

13. Ozkol $\mathrm{H}$, Tuluce $\mathrm{Y}$ and Koyuncu I. Subacute effect of cigarette smoke exposure in rats: protection by pot marigold (Calendula officinalis L.) extract. Toxicol Ind Health. 2012; 28:3-9. | Article | PubMed

14. Tuluce $Y$, Ozkol H, Koyuncu I and Ine H. Gastroprotective effect of small centaury (Centaurium erythraea $\mathrm{L}$ ) on aspirin-induced gastric damage in rats. Toxicol Ind Health. 2011; 27:760-8. | Article | PubMed

15. Dixit N, Baboota S, Kohli K, Ahmad S and Ali J. Silymarin: A review of pharmalogical aspects and bioavilability enhancement approaches. Indian J Pharamacol. 2007; 39:172-179. | Article

16. Comelli MC, Mengs U, Schneider C and Prosdocimi M. Toward the definition of the mechanism of action of silymarin: activities related to cellular protection from toxic damage induced by chemotherapy. Integr Cancer Ther. 2007; 6:120-9. | Article | PubMed

17. Tuluce $\mathrm{Y}, \mathrm{Ozkol} \mathrm{H}$ and Koyuncu I. Photoprotective effect of flax seed oil (Linum usitatissimum L.) against ultraviolet C-induced apoptosis and oxidative stress in rats. Toxicol Ind Health. 2012; 28:99-107. | Article | PubMed

18. Faezizadeh Z, Gharib A and Godarzee M. In-vitro and In-vivo Evaluation of Silymarin Nanoliposomes against Isolated Methicillin-resistant Staphylococcus aureus. Iran J Pharm Res. 2015; 14:627-33. | PubMed Abstract | PubMed FullText

19. Jahromi H., Abedi $H$, Hashemi S., Jashni $H$, Jahromi $Z$ and Pourahmadi $M$. The effect of silymarin on spermatogenesis process in rats. Int $\mathrm{J}$ Medical Research Health Sciences. 2016, 6:146-150.

20. Jaffe BM and Behman NR. Methods of hormone radioimmunoassay. Academic press. 1974; 896-899.

21. Santner SJ, Santen RJ, Kulin HE and Demers LM. A model for validation of radioimmunoassay kit reagents: measurement of follitropin and lutropin in blood and urine. Clin Chem. 1981; 27:1892-5. | Article | PubMed

22. Drury R and Wallington E. Carleton's Histological Technique. $4^{\text {th }}$ ed. Oxford. Univ. Press, New York. 1980.

23. Tanaka $H$, Fujisawa $M$, Okada $H$ and Kamidono S. Apoptosis-related proteins in the testes of infertile men with varicocele. BJU Int. 2002; 89:905-9. | Article | PubMed

24. Kilinc F, Guvel S, Kayaselcuk F, Aygun C, Egilmez T and Ozkardes H. p53 expression and apoptosis in varicocele in the rat testis. J Urol. 2004; 172:2475-8. | Article | PubMed

25. Hartgens $\mathrm{F}$ and Kuipers $\mathrm{H}$. Effects of androgenic-anabolic steroids in athletes. Sports Med. 2004; 34:513-54. | PubMed

26. Reddy YV, Reddy PS, Shivalingam MR and Gamini CP. Dose dependent alterations in epididymal sperm counts of cisplatin or carboplatin treated male waster rats. J Pharmaceut Sci Res. 2009; 1:167-172. | Pdf

27. Mohd Mutalip SS, Surindar Singh GK, Mohd Shah A, Mohamad M, Mani $V$ and Hussin SN. Histological changes in testes of rats treated with testosterone, nandrolone, and stanozolol. Iran J Reprod Med. 2013; 


\section{1:653-8. | PubMed Abstract | PubMed FullText}

28. De Souza BR, Mathias LS, De Souza TI and Camargo IC. Histopathological and morphometric evaluation in the testis and epididymis of adult rats submitted to a recovery period after treatment with anabolic steroid, alcohol, and/or nicotine. J Interdiscip Histopathol. 2017; 5:92-98.

29. Muraoka K. Effects of testosterone replacement on renal function and apoptosis on mesangial and renal tubule cells in rats. Yonago Acta Medica. 2001; 41:37-44.

30. Shiono M. The effect of aging and exogenous testosterone replacement on nitric oxide concentration and activity of nitric oxide synthase in the rat corpus cavernosum. Yonago Acta Medica. 2001; 44:45-53. | Pdf

31. Rasul $\mathrm{K} \mathrm{H}$ and Aziz F M. The Effect of sustanon (testosterone derivatives) taken by athletes on the testis of rat. JJBS. 2012; 5:113-119. | Pdf

32. Oda SS and EI-Ashmawy IM. Adverse effects of the anabolic steroid, boldenone undecylenate, on reproductive functions of male rabbits. Int J Exp Pathol. 2012; 93:172-8. | Article | PubMed Abstract | PubMed FullText

33. Al-Alwany EA, Al-Saadi H K and Hassan AJ. Effect of sustanon on some immunological and hormonal parameters in rats. Int J Chem Sci. 2015; 13:1947-1960.

34. Majhool AB and Zenad KH. Histopathological effects of different doses of anabolic androgenic steroid (Sustanon) on liver and testes of male rats. IJABR. 2016; 6:239-246.

35. Grokett BH, Ahmad N and Warren DW. The effects of an anabolic steroid (oxandrolone) on reproductive development in the male rat. Acta Endocrinol (Copenh). 1992; 126:173-8. | Article | PubMed

36. Feinberg MJ, Lumia AR and McGinnis MY. The effect of anabolicandrogenic steroids on sexual behavior and reproductive tissues in male rats. Physiol Behav. 1997; 62:23-30. | Article | PubMed

37. Mesbah SF, Shokri S, Karbalay-Doust S and Mirkhani H. Effects of nandrolonedecanoate on ultrastructure of testis in male adult rats. Iran J. med. Sci. 2008; 33:94 -100.

38. Hijazi M M, Azmi MA, Hussain A, Naqvi SN, Perveen R and Hijazi S. Androgenic anabolic steroidal-based effects on the morphology of testicular structures of albino rats. Pakistan J. Zool. 2012; 44:1529-1537. I Pdf

39. Sakr SA and Okdah YA. Histological and histochemical alteration induced in the testicular tissue of mice intoxicated with benomyle. J. Biol. Sci. 2004; 4:498-500. | Article

40. Ksheerasagar RA and Kaliwal BB. Effect of mancozeb on thyroid, testis, accessory reproductive organs and biochemical constituents in albino mice. Recent Res Sci Technol. 2010; 2:7-17.

41. Earnshaw WC, Martins LM and Kaufmann SH. Mammalian caspases: structure, activation, substrates, and functions during apoptosis. Annu Rev Biochem. 1999; 68:383-424. | Article | PubMed

42. Fisher DE. The $\mathbf{p} 53$ tumor suppressor: critical regulator of life $\&$ death in cancer. Apoptosis. 2001; 6:7-15. | PubMed

43. Kim JM, Ghosh SR, Weil AC and Zirkin BR. Caspase-3 and caspaseactivated deoxyribonuclease are associated with testicular germ cell apoptosis resulting from reduced intratesticular testosterone. Endocrinology. 2001; 142:3809-16. | Article | PubMed

44. Beumer TL, Roepers-Gajadien HL, Gademan IS, van Buul PP, Gil-Gomez $G$, Rutgers DH and de Rooij DG. The role of the tumor suppressor p53 in spermatogenesis. Cell Death Differ. 1998; 5:669-77. | Article | PubMed

45. Oldereid NB, Angelis PD, Wiger R and Clausen OP. Expression of Bcl-2 family proteins and spontaneous apoptosis in normal human testis. $\mathrm{Mol}$ Hum Reprod. 2001; 7:403-8. | PubMed

46. Shetty G, Shao SH and Weng CC. p53-dependent apoptosis in the inhibition of spermatogonial differentiation in juvenile spermatogonial depletion (Utp14bjsd) mice. Endocrinology. 2008; 149:2773-81. | Article | PubMed Abstract | PubMed FullText

47. Gestl EE and Anne Bottger S. Cytoplasmic sequestration of the tumor suppressor $\mathrm{p} 53$ by a heat shock protein $\mathbf{7 0}$ family member, mortalin, in human colorectal adenocarcinoma cell lines. Biochem Biophys Res Commun. 2012; 423:411-6. | Article | PubMed
48. Pradhan SC and Girish C. Hepatoprotective herbal drug, silymarin from experimental pharmacology to clinical medicine. Indian J Med Res. 2006; 124:491-504. | PubMed

49. Oral B, Guney M, Ozguner F, Karahan N, Mungan T, Comlekci S and Cesur G. Endometrial apoptosis induced by a $900-\mathrm{MHz}$ mobile phone: preventive effects of vitamins E and C. Adv Ther. 2006; 23:957-73. I PubMed

50. Moshtaghion SM, Malekinejad H, Razi M and Shafie-Irannejad V. Silymarin protects from varicocele-induced damages in testis and improves sperm quality: evidence for E2f1 involvement. Syst Biol Reprod Med. 2013; 59:270-80. | Article | PubMed

\section{Citation:}

El-hanbuli HM, Abo-sief AF and Mostafa T. Protective effect of silymarin on the testes of rats treated with anabolic androgenic steroid: A biochemical, histological, histochemical and immunohistochemical study. J Histol Histopathol. 2017; 4:10.

http://dx.doi.org/10.7243/2055-091X-4-10 